Gazi University
Journal of Science
$\mathrm{http} / / /$ dergipark.gov.tr/gujs

\title{
Evaluation of the Academic Achievement of Vocational School of Higher Education Students Through Artificial Neural Networks
}

\author{
Omur Kaya KALKAN* (D), Tolga COSGUNER \\ Pamukkale University, Department of Educational Measurement and Evaluation, 20160, Denizli, Turkey
}

\section{Highlights}

- Mathematics lecture achievement is the most important predictor of academic achievement.

- Turkish lecture achievement is the second significant predictor of academic achievement.

- The mathematics and Turkish lecture achievement are followed by academic self-efficacy.

Article Info

Received:01 Nov 2020

Accepted:13 Dec 2020

\section{Keywords}

Vocational education Artificial neural networks,

Academic achievement Academic self-efficacy Higher education admission exam

\begin{abstract}
This study aimed to determine the importance levels of mathematics lecture achievement, Turkish lecture achievement, Higher Education Admission Exam score, academic self-efficacy, attitude towards vocational education, academic motivation and mother and father education on the academic achievement of vocational schools of higher education students using the artificial neural network method. The data was obtained through 468 students from vocational schools of higher education at two different universities in Turkey. According to the quantitative research methodology, the correlational research design was used. The artificial neural network analysis results revealed that mathematics lecture achievement, Turkish lecture achievement and academic self-efficacy were the most critical variables that predicted the academic achievement of vocational schools of higher education students. These variables were followed by mother education level, father education level, attitude towards vocational education, Higher Education Admission Exam score and academic motivation. The results suggest that the effectiveness of the Higher Education Admission Exam score, which contributes very little to predict the academic achievement of vocational education students, need to be more questioned.
\end{abstract}

\section{INTRODUCTION}

Vocational education is designed to provide the theoretical and practical training necessary for individuals to obtain a profession and to provide them with professional skills, attitudes and habits [1]. Vocational training at the associate degree programme level in Turkey is carried out in vocational schools of higher education (VSHEs). A VSHE is defined in Higher Education Law number 2547 as 'a higher education institution that aims to train qualified workforce for certain professions, continues education for two or three terms a year, gives the associate degree' [2]. In Turkey, as of 2020, there are 3,002,964 students $(1,526,121$ female and 1,476,483 male) enrolled in 402 colleges and 1,022 VSHEs [3].

Several factors affect student achievement and education quality in VHSEs. For example, such environmental factors as the physical infrastructure of the VSHE, its equipment and academic staff, the student's socio-economic level and family, adaptation and accommodations, affect student achievement and education quality [4-7]. According to Aş1lığlu, Çay and Şanlıbaba (2016) [4] the lack of technological equipment and laboratories, insufficiency of libraries and reading halls and lack of social activities (e.g. food, canteens, sports, health, guidance, shelter etc.) which are factors related with establishment places and conditions of VSHEs, are also negatively affecting the quality of education. In addition to this, such factors as adaptation, accommodation, peer groups, economic conditions, habits gained during primary and secondary education, family support, education level of parents and attitudes of academic staff have an impact on students' achievement [7-9]. The concerns of VSHE students being unable to find employment 
after graduation and being unable to do the profession they were trained in cause their achievement levels to decrease [4].

Based on the results of previous studies in the literature, it can be said that academic self-efficacy, academic motivation and attitude towards vocational education can have an impact on students' academic achievement [10-17]. Perceived self-efficacy expresses the beliefs of the individual in their ability to organise and execute actions required to achieve certain gains [10]. Self-efficacy is an important variable that can be used to explain behaviour, which is a function of many variables [11]. Self-efficacy shows a positive and significant relationship with academic achievement [12-14], and self-efficacy is a predictor of academic achievement [15-17].

Academic motivation can be defined as the generation of intrinsic energy that students need for academic processes [18]. The low motivation of students can lead this process to failure, as it reduces their active participation in learning processes. This suggests that motivation is an essential factor affecting the teaching-learning process [19]. The results of some studies indicated that academic motivation shows a positive and significant relationship with academic achievement [20-22], and motivation is a predictor of academic achievement [23].

Attitude towards vocational education refers to students' attitudes towards the theoretical and applied education (i.e. gaining professional skills, attitudes and habits) required for having a profession during education. Students who have positive attitudes, interests and believes towards vocational education approach in their schools become more adaptive [24]. Generally, a positive attitude results in higher achievement [25].

Traditionally, multiple regression models and their extensions (e.g. principal component regression analysis, stepwise ordered least squares regression etc.) can be utilised to determine the predictive levels of those mentioned above cognitive and affective variables in students' academic achievement. As an alternative, artificial neural networks (ANNs) can be used for this purpose. Theoretically, ANNs have some significant advantages over standard statistical approaches. ANNs allow for random nonlinear relationships between independent and dependent variables and all possible interactions among dependent variables [26]. Thus, in ANN applications, it becomes possible to reveal the existence of nonlinear effects among variables that cannot be modelled using other linear regression techniques [27]. In addition, ANNs do not require many assumption tests (e.g. outliers, multicollinearity, normality, linearity, the covariance of residuals etc.; [28]), which are required for linear regression analysis. Due to these advantages, the ANN method was preferred within the scope of the present study.

The origin of ANN studies is based on a computational element model called the McCulloch-Pitts neuron. In this computing element, the weighted sum of inputs to the element is obtained, and then a threshold logic operation is performed [29]. ANN models are based on connecting a series of nonlinear computing units called neurons that perform a simple task [30]. Therefore, ANNs can be considered a highly simplified model of the structure of the biological neural network [31]. In this context, ANNs are basically expressed as mathematical algorithms that can be used to solve complex problems by modelling the function of the human brain [27]. Providing a new perspective into investigating fundamental issues about the progression of cognitive development [32,33], ANN models are widely used in classification and generalised regression applications $[26,27,30]$.

Some studies have addressed VSHE students' mathematics achievement, mathematics anxiety levels [3436], life satisfaction and self-esteem [37], hopelessness levels [38], creativity levels [39] and socioeconomic levels [40]. The scope of these studies is usually limited by specific variables, such as attitude towards a particular latent trait or mathematics achievement. In addition, no research has evaluated students' previous academic achievements (e.g. Higher Education Admission Exam [HEAE] score) together with their current academic achievement at VHSEs. In the global competition in the world, the need for a qualified labour force that has received professional training is a problem that is often brought to the agenda by Turkey [38]. One of the most critical indicators of excellent professional education is academic achievement. Academic achievement is considered very important for students as well as their 
families and their environment, as it enables students to prepare for their professional and social lives in a well-equipped manner and to shape their future. Academic achievement at any level is a current and previous cumulative function of family, community and school experiences [41]. Therefore, the academic achievement should be addressed from a comprehensive perspective. The present study aimed to determine the importance levels of mathematics lecture achievement, Turkish lecture achievement, HEAE score, academic self-efficacy, attitude towards vocational education, academic motivation and mother and father education on the academic achievement of VSHE students using the ANN method.

The following research questions derived from the aim are answered in this study:

1. What are the importance levels of mathematics lecture achievement, Turkish lecture achievement, Higher Education Admission Exam score, academic self-efficacy, attitude towards vocational education, academic motivation and mother and father education on the academic achievements of VSHE students at Hacettepe Ankara Chamber of Industry 1st Organised Industrial Zone?

2. What are the importance levels of mathematics lecture achievement, Turkish lecture achievement, Higher Education Admission Exam score, academic self-efficacy, attitude towards vocational education, academic motivation and mother and father education on the academic achievements of VSHE students at Pamukkale University Denizli Technical Sciences?

3. What are the importance levels of mathematics lecture achievement, Turkish lecture achievement, Higher Education Admission Exam score, academic self-efficacy, attitude towards vocational education, academic motivation and mother and father education on the academic achievements of VSHE students?

By determining the relative importance levels of the specified variables on the academic achievement of VSHE students, the study aims to contribute to the decisions of vocational education policymakers by providing empirical evidence. In addition to this, it will be possible to contribute to the evaluation of demographic, affective and cognitive factors that affect the academic achievement of VSHE students from a broad perspective.

\section{MATERIAL AND METHOD}

\subsection{Research Design}

A correlational research method, a quantitative research design, was used in this study. Correlational studies are used to determine the relationship between two or more variables. If the relationship between or among these variables is large enough, one variable's score can be estimated using the scores of the other variable. In this respect, the current research can be considered a predictive type of correlational study [42].

\subsection{Participants}

The participants in the study consisted of 468 volunteer students enrolled at the Hacettepe Ankara Chamber of Industry (HACI) $1^{\text {st }}$ Organised Industrial Zone (OIZ) VSHE and Pamukkale University Denizli Technical Sciences (PAUDTS) VSHE during the fall semester of the 2017-2018 academic year. In the first step, the data was collected from 737 volunteers; however, it was noticed that 269 of them were not HEAE scores, so 269 students were removed from the study group. Participants were determined by using the convenience sampling method as a result of the difficulty in selecting a completely random sample in educational research. However, it should be noted that there can be a possibility that samples determined using this method may be biased [42]. A total of 263 students, $56(21.3 \%)$ females and $207(81.1 \%)$ males, from HACI $1^{\text {st }}$ OIZ VSHE, participated in the research. A total of 205 students, $8(3.9 \%)$ female and 197 $(96.1 \%)$ male, from the PAUDTS VSHE, participated in the study. The distribution of students, according to VSHEs and departments, is presented in Table 1. 
Table 1. The distribution of students according to VSHEs and departments

\begin{tabular}{lcccc}
\hline Departments & \multicolumn{2}{c}{ HACI 1 $^{\text {st }}$ OIZ VSHE } & \multicolumn{2}{c}{ PAUDTS VSHE } \\
& $f$ & $\%$ & $f$ & $\%$ \\
\hline Electricity & 81 & 30.8 & 82 & 40.0 \\
Machine & 71 & 27.0 & 78 & 38.0 \\
Alternative Energy Sources & 43 & 16.3 & 45 & 22.0 \\
Industrial Product Design & 68 & 25.9 & $-^{*}$ & $-^{*}$ \\
Total & 263 & 100 & 205 & 100 \\
\hline
\end{tabular}

* PAUDTS VSHE does not have an industrial product design department

The education levels of the parents of the VSHE students are presented in Table 2.

Table 2. Education levels of the parents of the VSHE students

\begin{tabular}{lllll}
\hline Education level & \multicolumn{2}{c}{ Mother } & \multicolumn{2}{c}{ Father } \\
\cline { 2 - 5 } & $f$ & \multicolumn{1}{c}{$\%$} & $f$ & $\%$ \\
\hline Not literate & 23 & 4.9 & 6 & 1.3 \\
Literate (without diploma) & 15 & 3.2 & 9 & 1.9 \\
Primary school & 232 & 49.6 & 172 & 36.8 \\
Secondary school & 83 & 17.7 & 99 & 21.2 \\
High school & 88 & 18.8 & 121 & 25.9 \\
Associate's or bachelor's degree & 25 & 5.3 & 56 & 12.0 \\
Master's or doctorate & 2 & .4 & 5 & 1.1 \\
Total & 468 & 100.0 & 468 & 100.0 \\
\hline
\end{tabular}

Table 2 shows that the mother education level and father education level of the VSHE students are concentrated at the primary school level.

\subsection{Data Collection Tools}

The data of the study were obtained through a demographic information form, the Academic Self-Efficacy Scale, the Academic Motivation Scale and the Attitudes Towards Vocational Education Scale.

\section{Academic Self-Efficacy Scale}

The scale developed by Owen and Foreman (1988) [43] was adapted to Turkish by Ekici (2012) [44]. It consists of 33 items that can be rated on a 5-point Likert-type scale. The scale has a three-factor structure; the Cronbach's Alpha $(\mathrm{Cr} \alpha)$ reliability coefficient was reported as .82 for the social status sub-dimension, .82 for the cognitive applications sub-dimension and .90 for the technical skills sub-dimension. Within the scope of the research, $\mathrm{Cr} \alpha=.76$ for the social status sub-dimension of the scale, $\mathrm{Cr} \alpha=.89$ for the cognitive applications sub-dimension and $\mathrm{Cr} \alpha=.53$ for the technical skills sub-dimension.

\section{$\underline{\text { Academic Motivation Scale }}$}

The scale was developed by Bozanoğlu (2004) [18] and consists of 20 items that can be rated as a 5-point Likert-type scale. The scale has a three-factor structure: self-transcendence, using knowledge and exploration. The test-retest reliability of the scale was reported as .87. It was stated that the internal consistency coefficients varied between .77-.85 at different times for the same groups and between .77-.86 for different groups. For the current study, the reliability coefficient of the scale was found as $\mathrm{Cr} \alpha=.92$.

\section{Attitudes Towards Vocational Education Scale}

The scale developed by Kalkan (2014) [45] consists of 35 items that can be rated as a 5-point Likert-type scale. The reliability coefficient of the scale was reported as $\operatorname{Cr} \alpha=.97$. Within the scope of the research, the reliability coefficient of the scale was found as $\mathrm{Cr} \alpha=.95$. 


\subsection{Data Analysis}

Frequency $(f)$, percentage $(\%)$, mean $(M)$, median, mode, standard deviation $(S S)$, and the skewness coefficient $(S C)$ were used to present descriptive statistics. In addition, Cronbach's Alpha $(\mathrm{Cr} \alpha)$ was used to report the reliability coefficients of the scales. In the ANN analyses, academic achievement was the dependent variable. In this study, academic achievement refers to the Cumulative Grade Point Average (CGPA). The CGPA an average of the weighted grades of all of the courses divided by the total credits of the courses that the student has taken since from the first registration to the VHSE. The academic selfefficacy, attitude towards vocational education, academic motivation, Turkish lecture achievement, mathematics lecture achievement, HEAE score, mother education level and father education level were the independent variables. The mathematics lecture achievement score was obtained by taking the arithmetic average achievement of students in Mathematics I and Mathematics II courses. Similarly, Turkish lecture achievement scores were obtained by taking the achievement average of students' Turkish Language I and Turkish Language II lectures. For the ANN analyses, 100 replicates were performed. The power of predicting the dependent variable for each independent variable was obtained by taking the average of the importance levels obtained from these 100 analyses. In the ANN analyses, $30 \%$ of the data set was allocated to the testing of networks, while $70 \%$ was used for the training of networks.

\section{THE RESEARCH FINDINGS AND DISCUSSION}

Descriptive statistics of Academic Self-Efficacy Scale, Academic Motivation Scale and Attitudes Towards Vocational Education Scale scores are presented in Table 3. Table 3 showed that the SCs of all scales were within \pm 1 limits. Therefore, it can be said that the scale scores did not show a significant deviation from the normal distribution $[46,47]$.

Table 3. Descriptive statistics of scale scores

\begin{tabular}{lllllll}
\hline Scales & $n$ & $M$ & Median & Mode & SD & SC \\
\hline Academic Self-Efficacy & 468 & 105.48 & 105.50 & 105 & 19.43 & -0.51 \\
Academic Motivation & 468 & 71.67 & 73 & 77 & 14.23 & -0.60 \\
Attitudes Towards & 468 & 138.62 & 141.50 & 135 & 22.97 & -0.59 \\
Vocational Education & & & & & & \\
\hline
\end{tabular}

The ANN analysis results regarding the importance levels of independent variables on the academic achievement of HACI $1{ }^{\text {st }}$ OIZ VSHE students are presented in Figure 1.

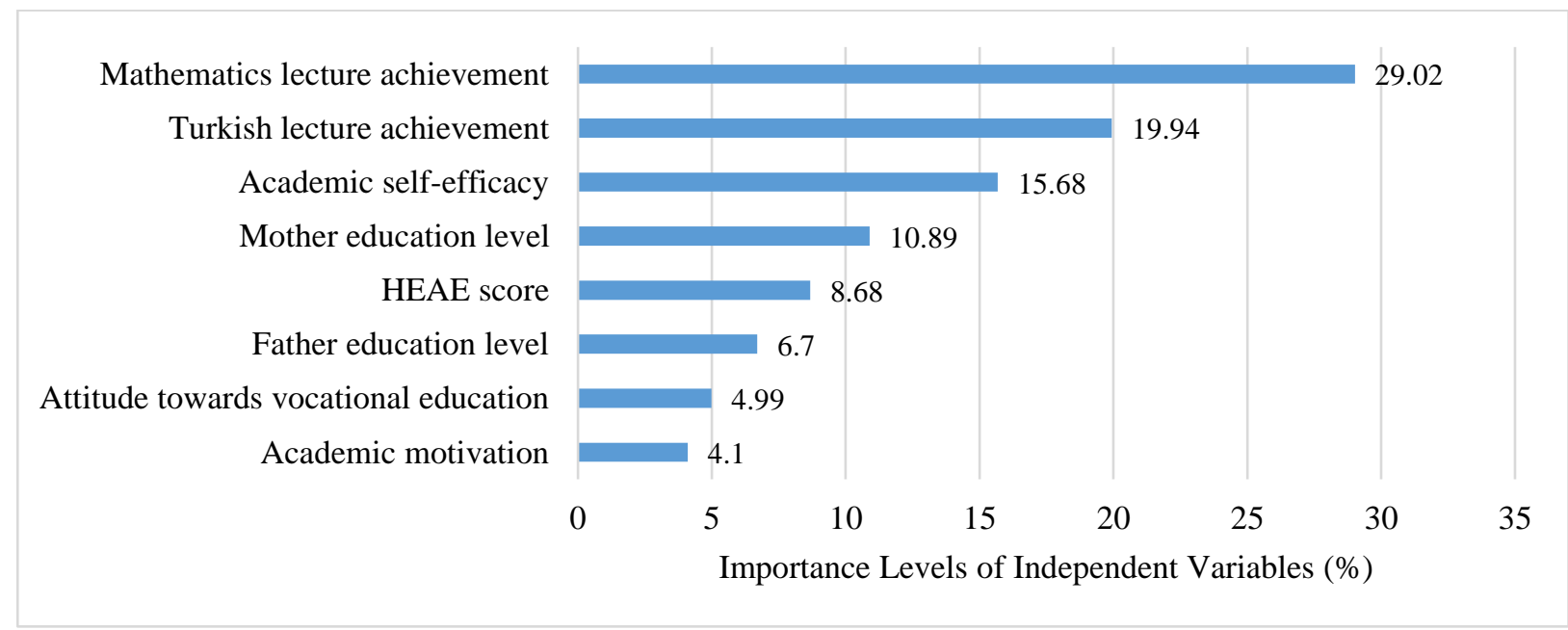

Figure 1. ANN analysis results regarding the importance levels of independent variables in predicting academic achievement of HACI $1^{\text {st }}$ OIZ VSHE students 
The ANN analysis results showed that the most crucial variable in predicting the academic achievement of HACI $1^{\text {st }}$ OIZ VSHE students was mathematics lecture achievement. Mathematics lecture achievement was followed by Turkish lecture achievement. As seen in Figure 1, the order of variables from the highest to lowest was as follows: mathematics lecture achievement, and Turkish lecture achievement, academic selfefficacy, mother education level, HEAE scores and father education level, attitude towards vocational education and academic motivation.

The ANN analysis results regarding the importance levels of independent variables on the academic achievement of PAUDTS VSHE students are presented in Figure 2.

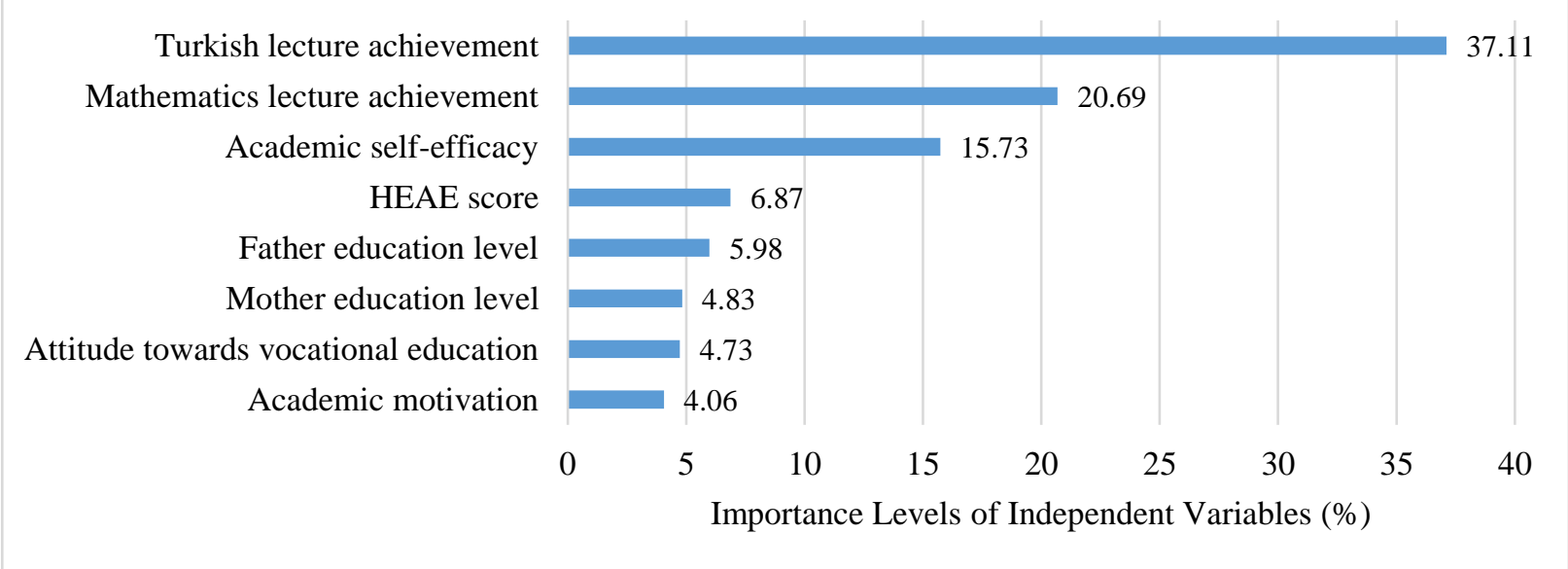

Figure 2. ANN analysis results regarding the importance levels of independent variables in predicting academic achievement of PAUDTS VSHE students

The ANN analysis results showed that the most crucial variable in predicting the academic achievement of PAUDTS VSHE students was Turkish lecture achievement. Turkish lecture achievement was followed by mathematics lecture achievement. As seen in Figure 2, the order of variables from the highest to lowest was as follows: Turkish lecture achievement, and mathematics lecture achievement, academic self-efficacy, HEAE scores, father education level, mother education level, attitude towards vocational education and academic motivation.

According to the results, Turkish lecture achievement in PAUDTS VSHE and mathematics lecture achievement in HACI $1^{\text {st }}$ OIZ VSHE were the most effective predictors of students' academic achievement. The average of PAUDTS VSHE students' Turkish lecture achievement $(M=2.36, S D=0.70)$ was higher than their mathematics lecture achievement $(M=2.15, S D=1.20)$. Conversely, HACI $1^{\text {st }}$ OIZ VSHE students' average of mathematics lecture achievement $(M=1.64, S D=1.28)$ was higher than the average of Turkish lecture achievement $(M=1.45, S D=0.95)$. This situation can be a reason of the change in the importance levels in both Turkish and mathematics lecture achievement at VSHEs. While Turkish and mathematics lecture achievement and academic self-efficacy were the most important predictors of academic achievement in both vocational schools, attitude towards vocational education and academic motivation were the least important variables. The results also suggest that HEAE scores, mother education level and father education level were moderately important variables.

The ANN analysis results regarding the importance levels of independent variables on the academic achievement of VSHE students are presented in Figure 3. 


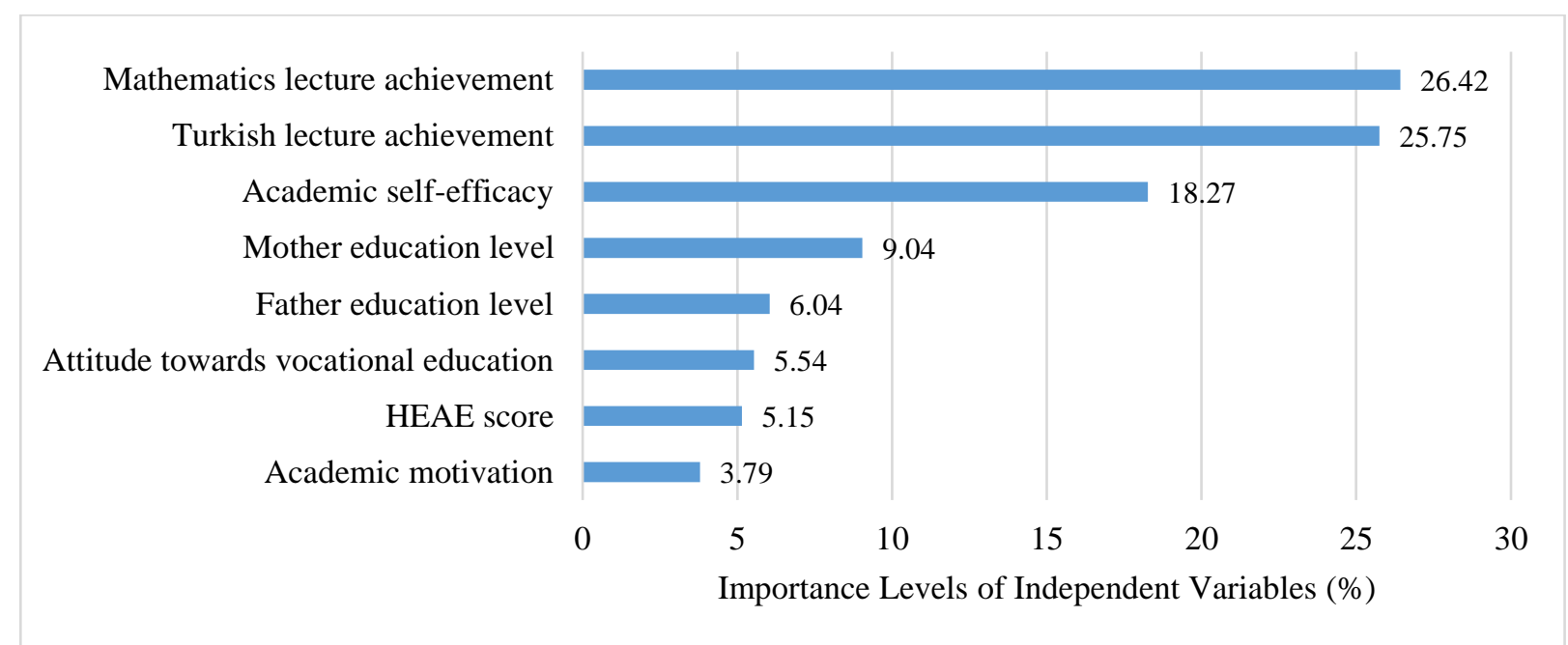

Figure 3. ANN analysis results regarding the importance levels of independent variables in predicting academic achievement of VSHE students

The ANN analysis results showed that the most crucial variable in predicting the academic achievement of VSHE students was mathematics lecture achievement. Mathematics lecture achievement was followed by Turkish lecture achievement, with little difference between them. Mathematics lecture achievement and Turkish lecture achievement were the foregoing variables that predict the academic achievement of VSHE students. This finding can be explained by the fact that the departments considered within the scope of the study admit students according to their HEAE Basic Proficiency Test scores, in which the mathematics and Turkish subject weight is much more. Parlak and Tatlidil (2013) [48] state that the most influential variables in predicting secondary school achievement scores are mathematics and Turkish course achievement scores. In addition, it has been stated that there is a positive and high-level correlation between mathematics and Turkish achievements [49].

Mathematics lecture achievement and Turkish lecture achievement were followed by academic selfefficacy. This result was supported by the past literature in a way that some studies in the literature have reported that self-efficacy is a significant predictor of academic achievement [15-17]. Sarier (2016) [50] states that among factors related to the student, the factor affecting academic achievement the most is selfefficacy. In addition, it has been stated that there is a positive and significant relationship between selfefficacy and academic achievement [12-14,51,52].

Academic self-efficacy was followed by mother education level and father education level, respectively. Mahigir, Venkatesh Kumar and Karimi (2012) [9] state that parental education level is a predictor of academic success. Gürsakal (2012) [8] states that the achievement levels of students differ according to the education level of the parents. In addition, studies have revealed that mother and/or father education levels are related to mathematics or Turkish achievement (e.g. [53-59]).

Mother and father education level was followed by the attitude towards vocational education, HEAE score and academic motivation, respectively. It can be said that developing a positive attitude towards vocational education is not enough to predict academic achievement at a critical level. In a meta-analysis study, Kinay (2012) [60] examined 36 studies that address the predictive validity of university admission exams (UAE), and 147 sub-studies were obtained from these studies. The author reported that the mean effect size value of the UAE predictive validity was positive and small (0.193). The fact that HEAE scores are not among the most important predictors of the VSHE students' academic achievement can be evaluated from this perspective. The least important variable in predicting the academic achievement of the VSHE students was academic motivation. The reasons-such as the negative opinions and concerns of the students of the VSHEs about the numerical lectures, thoughts of being unable to find employment and not caring about having the necessary knowledge in their lectures - may cause their academic motivation to decrease $[4,34,36,61]$. Possibly, these reasons have led to academic motivation being the least significant predictor of academic achievement. 


\section{CONCLUSIONS}

The current study evaluated the importance levels of mathematics lecture achievement, Turkish lecture achievement, HEAE score, academic self-efficacy, attitude towards vocational education, academic motivation and mother and father education on the academic achievement of VSHE students using the ANN method.

As a result, mathematics lecture achievement, Turkish lecture achievement and academic self-efficacy have total importance of $70 \%$ in predicting the academic achievement of the VSHE students. Therefore, policymakers and researchers who focus on the academic achievements of VSHE students are advised to prioritise the applications and improvement of the specified variables. Mother and father education levels together have a $15 \%$ weight in predicting academic achievement. Studies that aim to determine which of the education levels of mothers and fathers have a higher relationship with academic achievement will help to deepen what we know about this issue. A positive attitude towards vocational education has the potential to positively contribute to students' attitude toward their schools and increase their academic success. Therefore, practices that will improve students' attitudes and perceptions towards vocational education can be encouraged. Conversely, the fact that HEAE scores are one of the least significant variables in predicting the academic achievement of the VSHE students indicates that the predictive validity of HEAE scores should be considered in more detail. In addition, regarding the relationship between low-level academic motivation and failure, it can be expected that practices that will improve students' academic motivation will positively contribute to the teaching-learning process and academic achievement.

Besides the significant contributions, there are some limitations of this study deserve to be mentioned. In ANN analyses, the importance levels of the independent variables for the dependent variable may differ in the analyses. Therefore, Toprak (2017) [62] performed 50 replications for ANN analyses. In the present study, 100 replications were conducted to obtain robust results. However, there is no definite rule in the literature regarding the number of replications adequate to provide robust ANN analysis results. This issue needs to be addressed in the future studies. In addition to this, it should be noted that the way of sampling may be biased due to the use of convenience sampling method. Therefore, it is recommended to repeat a similar study with a larger sampling group in order to increase the generalizability of the results.

\section{ACKNOWLEDGEMENTS}

A part of this study was presented as an oral presentation at the $4^{\text {th }}$ International Congress on Education, Distance Education and Educational Technology (ICDET) held on 23-24, November 2018, in Antalya, Turkey. The authors thank the Pamukkale University Scientific Research Projects Coordination Unit for their support for participation in the congress with the grant fund number 2018KKP285(2018KRM002).

\section{FUNDING}

The authors wish to thank the Hacettepe University Scientific Research Projects Coordination Unit for the Scientific Research Projects Grant funding number SHD-2017-14622.

\section{CONFLICTS OF INTEREST}

No conflict of interest was declared by the authors.

\section{REFERENCES}

[1] Vural, M., "Öğrencilerin gelir düzeyleri ile akademik başarıları arasındaki ilişki üzerine bir araştırma", Akademik Bakış Dergisi, 35: 1-18, (2013).

[2] Resmi Gazete, "Yükseköğretim Kanunu”, Say1: 17506, Ankara, (1981).

[3] https://istatistik.yok.gov.tr. Access Date: 31.10 .2020 
[4] Aşılığlu, F., Çay, R. D. and Şanlıbaba, P., "Kalecik Meslek Yüksekokulu öğrencilerinin başarı düzeylerinin bazı değişkenler açısından incelenmesi”, Electronic Journal of Vocational Colleges, 6(1): 79-88, (2016).

[5] Çolakoğlu, J., "Yaşam boyu öğrenmede motivasyonun önemi”, Milli Eğitim Dergisi, 2: 155-156, (2002).

[6] Henden R. and Tunç A., "Mesleki ve teknik öğretimde sınavsız geçiş uygulamaları", Milli Eğitim Dergisi, 165: 165-171, (2005).

[7] Şeker, R., Çınar, D. and Özkaya, A., "Çevresel Faktörlerin Üniversite Öğrencilerinin Başarı Düzeyine Etkileri”, XIII. Ulusal Eğitim Bilimleri Kurultayı, Malatya, (2004).

[8] Gürsakal, S., "PISA 2009 öğrenci başarı düzeylerini etkileyen faktörlerin değerlendirilmesi”, Süleyman Demirel Üniversitesi İktisadi ve İdari Bilimler Fakültesi Dergisi, 17(1): 441-452, (2012).

[9] Mahigir, F., Venkatesh Kumar, G. and Karimi, A., "Parents socio economic background, mathematics anxiety and academic achievement", International Journal of Educational Administration and Policy Studies, 4(8): 177-180, (2012).

[10] Bandura, A., Self-efficacy: The Exercise of Control, Freeman, New York, (1997).

[11] Schunk, D. H., "Self-efficacy and academic motivation", Educational Psychologist, 26: 207-231, (1991).

[12] de Fátima Goulão, M., "The Relationship between Self-Efficacy and Academic Achievement in Adults' Learners", Athens Journal of Education, 1(3): 237-246, (2014).

[13] Meral, M., Colak, E., and Zereyak, E., "The relationship between self-efficacy and academic performance", Procedia-Social and Behavioral Sciences, 46: 1143-1146, (2012).

[14] Motlagh, S. E., Amrai, K., Yazdani, M. J., Abderahim, H. A., and Souri, H., "The relationship between self-efficacy and academic achievement in high school students", Procedia-Social and Behavioral Sciences, 15: 765-768, (2011).

[15] Alivernini, F. and Lucidi, F., "Relationship between social context, self-efficacy, motivation, academic achievement, and intention to drop out of high school: A longitudinal study", The Journal of Educational Research, 104(4): 241-252, (2011).

[16] Carroll, A., Houghton, S., Wood, R., Unsworth, K., Hattie, J., Gordon, L. and Bower, J., "Selfefficacy and academic achievement in Australian high school students: The mediating effects of academic aspirations and delinquency", Journal of Adolescence, 32(4): 797-817, (2009).

[17] Komarraju, M. and Nadler, D., "Self-efficacy and academic achievement: Why do implicit beliefs, goals, and effort regulation matter?", Learning and individual differences, 25: 67-72, (2013).

[18] Bozanoğlu, İ., “Akademik güdülenme ölçeği: Geliştirmesi, geçerliği, güvenirliği”, Ankara Üniversitesi Eğitim Bilimleri Fakültesi Dergisi, 37(2): 83-98, (2004).

[19] Kelecioğlu, H., “Güdülenme”, Hacettepe Üniversitesi Eğitim Fakültesi Dergisi, 7: 175-181, (1992). 
[20] Amrai, K., Motlagh, S. E., Zalani, H. A. and Parhon, H., "The relationship between academic motivation and academic achievement students", Procedia-Social and Behavioral Sciences, 15: 399-402, (2011).

[21] Firouznia, S., Yousefi, A. and Ghassemi, G., "The relationship between academic motivation and academic achievement in medical students of Isfahan University of Medical Sciences", Iranian Journal of Medical Education, 9(1): 79-84, (2009).

[22] Green, J., Nelson, G., Martin, A. J. and Marsh, H., "The causal ordering of self-concept and academic motivation and its effect on academic achievement", International Education Journal, 7(4): 534-546, (2006).

[23] Kabakci, I., Gulumbay, A.A. and Namlu, A.G., "The relationship between learning strategies and motivation of university students with academic success", In C. Crawford, N. Davis, J. Price, R. Weber \& D. Willis (Eds.), Proceedings of SITE 2003-Society for Information Technology \& Teacher Education International Conference, Albuquerque, New Mexico, 716-719, (2003).

[24] Öztürk, Z., "Mesleki ve teknik anadolu lisesi öğrencilerinin okula yabancılaşmaya yönelik görüşleri ve mesleki eğitime yönelik tutumları", Yüksek Lisans Tezi, Düzce Üniversitesi Sosyal Bilimler Enstitüsü, Düzce, 1-128, (2019).

[25] Weinburgh, M., "Gender differences in student attitudes toward science: A meta-analysis of the literature from 1970 to 1991", Journal of Research in science Teaching, 32(4): 387-398, (1995).

[26] Sargent, D. J., "Comparison of artificial neural networks with other statistical approaches: results from medical data sets", Cancer: Interdisciplinary International Journal of the American Cancer Society, 91(8): 1636-1642, (2001).

[27] Marengo, E., Longo, V., Robotti, E., Bobba, M., Gosetti, F., Zerbinati, O. and Di Martino, S., "Development of calibration models for quality control in the production of ethylene/propylene copolymers by FTIR spectroscopy, multivariate statistical tools, and artificial neural networks", Journal of Applied Polymer Science, 109(6): 3975-3982, (2008).

[28] Tabachnick, B. G. and Fidell, L. S., Using Multivariate Statistics, Pearson Education, Boston, (2007).

[29] McCulloch, W. S. and Pitts, W., "A logical calculus of the ideas immanent in nervous activity", The Bulletin of Mathematical Biophysics, 5(4): 115-133, (1943).

[30] Chtioui, Y., Bertrand, D., Devaux, M. F. and Barba, D., "Comparison of multilayer perceptron and probabilistic neural networks in artificial vision. Application to the discrimination of seeds", Journal of Chemometrics: A Journal of the Chemometrics Society, 11(2): 111-129, (1997).

[31] Yegnanarayana, B., Artificial Neural Networks, Prentice-Hall of India Private Limited, New Delhi, (2005).

[32] McClelland, J.D., Parallel distributed processing: Implications for cognition and development, In R.G.M. Morris (Ed.), Parallel distributed processing: Implications for psychology and neurobiology, Clarendon Press., Oxford, 8-45, (1989).

[33] Siegler, R.S., "Mechanisms of cognitive development", Annual Review of Psychology, 40: 353379, (1997). 
[34] Bekdemir, M., "Meslek yüksekokulu öğrencilerinin matematik kayg1 düzeylerinin ve başarılarının değerlendirilmesi”, Erzincan Üniversitesi Fen Bilimleri Enstitüsü Dergisi, 2(2): 169-189, (2009).

[35] Taşdemir, C., "Meslek yüksekokulu öğrencilerinin matematik kayg1 düzeylerinin bazı değişkenler açısından incelenmesi”, Bitlis Eren Üniversitesi Fen Bilimleri Dergisi, 2(2): 154$162,(2013)$.

[36] Durukan, S., Aygün, M., Aydın, İ. and Diril, H. Z., "Mesleki ve teknik eğitimde sınavsız geçişle ve sınavla gelen öğrencilerin matematik başarılarının değerlendirilmesi", Eğitim ve Öğretim Araştırmaları Dergisi, 4(3): 211-218, (2015).

[37] Dilmaç, B. and Ekşi, H., "Meslek yüksek okullarında öğrenim gören öğrencilerin yaşam doyumları ve benlik saygılarının incelenmesi”, Selçuk Üniversitesi Sosyal Bilimler Enstitüsü Dergisi, 20: 279-289, (2008).

[38] Kılıç, S., Tektaş, N. and Pala, T., "Devlet ve vakıf meslek yüksekokulu öğrencilerinin umutsuzluk düzeylerinin karşılaştırılması ve umutsuzluk düzeylerini etkileyen faktörlerin belirlenmesi”, Türkiye Sosyal Araştırmalar Dergisi, 182: 169-186, (2014).

[39] Çakmak, A., "Meslek yüksekokulu öğrencilerinin yaratıcılık düzeylerinin çeşitli değişkenler açısından incelenmesi”, Hacettepe Üniversitesi Sosyolojik Araştırmalar e-dergisi, (2010).

[40] Nartgün, Ş. S. and Yüksel, E., "Ahi Evran Üniversitesi Kaman Meslek Yüksekokulu öğrencilerinin sosyoekonomik düzeylerinin belirlenmesi”, Ahi Evran Üniversitesi Kırşehir Eğitim Fakültesi Dergisi, 10(2): 1-18, (2009).

[41] Rivkin, S. G., Hanushek, E. A. and Kain, J. F., "Teachers, schools, and academic achievement", Econometrica, 73(2): 417-458, (2005).

[42] Fraenkel, J. R., Wallen, N. and Hyun, H., How to Design and Evaluate Research in Education, McGraw Hill, NY, (2011).

[43] Owen, S. V. and Froman, R. D., "Development of a College Academic Self-Efficacy Scale", Annual Meeting of the National Council on Measurement in Education, New Orleans, L.A, (1988).

[44] Ekici, G., "Akademik öz-yeterlik ölçeği: Türkçe'ye uyarlama, geçerlik ve güvenirlik çalışması”, Hacettepe Üniversitesi Eğitim Fakültesi Dergisi, 43(43): 174-185, (2012).

[45] Kalkan, Ö. K., "Mesleki eğitime yönelik tutum ölçeği geçerlik ve güvenirlik çalışması", Trakya Üniversitesi Eğitim Fakültesi Dergisi, 4(1): 117-128, (2014).

[46] Cohen, L., Manion, L. and Morrison, K., Research methods in education, Routledge, NY (2018).

[47] Muthén, B. and Kaplan, D. A., "Comparison of some methodologies for the factor analysis of non-normal Likert variables", British Journal of Mathematical and Statistical Psychology, 38(2): 171-189, (1985).

[48] Parlak, B. and Tatlıdil, H., "8. Sınıf öğrencilerinin okul başarıları ile test puanları arasındaki ilişkinin çok boyutlu incelenmesi", International Symposium on Econometrics, Operations Research and Statistics, 335-350, (2013). 
[49] Güleç, S. and Alkış, S., "İlköğretim birinci kademe öğrencilerinin derslerdeki başarı düzeylerinin birbiri ile ilişkisi”, Elementary Education Online, 2(2): 19-27, (2003).

[50] Sarıer, Y, "Türkiye'de öğrencilerin akademik başarısını etkileyen faktörler: Bir meta-analiz çalışması”, Hacettepe Üniversitesi Eğitim Fakültesi Dergisi, 31(3): 609-627, (2016).

[51] Ayotola, A. and Adedeji, T., "The relationship between mathematics self-efficacy and achievement in mathematics", Procedia-Social and Behavioral Sciences, 1(1): 953-957, (2009).

[52] Klomegah, R. Y., "Predictors of academic performance of university students: an application of the goal efficacy model", College Student Journal, 41(2): 407-415, (2007).

[53] Çanakçı, O. and Özdemir, A. Ş., "Matematik başarısı ve anne baba eğitim düzeyi”, İstanbul Aydın Üniversitesi Dergisi, 7(25): 19-36, (2015).

[54] Dursun, Ş. and Dede, Y., "Öğrencilerin matematikte başarısını etkileyen faktörler: Matematik öğretmenlerinin görüşleri bakımından”, Gazi Eğitim Fakültesi Dergisi, 24(2): 217-230, (2004).

[55] Yenilmez, K. and Duman, A., "İlköğretimde matematik başarisini etkileyen faktörlere ilişkin öğrenci görüşleri”, Manas Üniversitesi Sosyal Bilimler Dergisi, 10(19): 251-268, (2008).

[56] Gelbal, S, "Sekizinci sınıf öğrencilerinin sosyoekonomik özelliklerinin Türkçe başarısı üzerinde etkisi”, Eğitim ve Bilim, 33(150): 1-13, (2008).

[57] Güvendir, M. A., "Öğrenci başarılarının belirlenmesi sınavında öğrenci ve okul özelliklerinin Türkçe başarısı ile ilişkisi”, Eğitim ve Bilim, 39(172): 163-180, (2014).

[58] Öztürk, P., "İlköğretim II. Kademe Türkçe dersi performans görevi başarı puanları ile akademik başarı ve derse yönelik tutum arasındaki ilişkinin değerlendirilmesi”, Yüksek Lisans Tezi, Karadeniz Teknik Üniversitesi Sosyal Bilimler Enstitüsü, Trabzon, 1-114, (2010).

[59] Mutluer, C. and Büyükkıdık, S., "PISA 2012 verilerine göre matematik okuryazarlı̆̆ının lojistik regresyon ile kestirilmesi”, Marmara Üniversitesi Atatürk Eğitim Fakültesi Eğitim Bilimleri Dergisi, 46: 97-112, (2017).

[60] Kınay, E., “Üniversite giriş sınavı yordama geçerliği çalışmalarının meta analizi”, Yüksek Lisans Tezi, Ankara Üniversitesi Eğitim Bilimleri Enstitüsü, Ankara, 1-110, (2012).

[61] Sarı, M., "Meslek Yüksekokullarında okuyan öğrencilerin sayısal derslerdeki başarısını olumsuz yönde etkileyen nedenlerin öğrenci görüşlerinden yararlanarak incelenmesi (Akdeniz Üniversitesi Teknik Bilimler Meslek Yüksekokulu örneği)", Eğitim ve Öğretim Araştırmaları Dergisi, 3(2): 297-301, (2014).

[62] Toprak, E.. and Gelbal, S., "Comparison of classification performances of mathematics achievement at PISA 2012 with the artificial neural network, decision trees and discriminant analysis", International Journal of Assessment Tools in Education, 7(4): 773-799, (2020). 